\title{
Hydro-geochemical Assessment of Seawater Intrusion in Freshwater Shallow Aquifer in Southeastern Coastal of Cuddalore District, Tamilnadu, India
}

\author{
K. Karthikeyan, N. Nagarajan, S. Sivaprakasam, K. Shakila
}

\begin{abstract}
As the coastal line of Tamilnadu is long, it may have been affected due to sea water intrusion by natural (sea level rise) and anthropogenic. Therefore, this study deals with the Hydro chemical assessment of seawater interruption in freshwater aquifer in Parangipettai region. For this assessment, the groundwater samples have been collected in various locations of Parangipettai region for both pre and post-monsoon period. The collected samples were tested by laboratory method for the identification of major cat ions and anions, namely TDS, EC, chloride, magnesium, Bicarbonate, calcium, sodium, potassium, and sulphate. The spatial maps for all the parameters were carried out using the ArcGIS 10.2 version for the purpose of better understanding the quality of groundwater. The results obtained through laboratory method are used to create Salinity and sodium risk of irrigation water in US salinity diagram, Gibbs diagram, permeability index and reconstructed diamond field of piper diagram using the watclast software. From the spatial maps, watclast diagrams and the standards recommended by WHO, BIS, and ISI, the SWI are discussed in detail to recommend the remedial measures to recover and restore the feature of groundwater in the Parangipettai region.
\end{abstract}

Keywords: Groundwater quality, Hydrochemical facies, Sea water Intrusion

\section{INTRODUCTION}

Groundwater is the precious resource and one of the major sources of freshwater. But, due to the demand of freshwater, it has been over exploited throughout the world for purpose of domestic, agricultural and industrial activities. The exploitation rate is higher than the recharge rate of groundwater annually. This is the major reason for seawater intrusion in freshwater aquifer. Therefore, understanding the quality of groundwater is very essential to study the SWI. In the process of analyzing the quality of GW, The Hydrochemistry plays a vital role; Since the GWSW is the integral component of the hydrological system of a coastal aquifer (N.C Mondal et al., 2010). SWI is a key crisis in the coastal zones across the globe.

Revised Manuscript Received on July 10, 2020

* Correspondence Author

Dr. K. Karthikeyan*, Associate Professor, Department of Civil Engineering, Annamalai University, Chidambaram, Tamilnadu, India.

Dr. N. Nagarajan, Associate Professor, Department of Civil Engineering, Annamalai University, Chidambaram, Tamilnadu, India.

Dr. S. Sivaprakasam, Associate Professor, Department of Civil Engineering, Annamalai University, Chidambaram, Tamilnadu, India.

K. Shakila, Post Graduate Student, Department of Civil Engineering, Annamalai University, Chidambaram, Tamilnadu, India.

(c) The Authors. Published by Blue Eyes Intelligence Engineering and Sciences Publication (BEIESP). This is an open access article under the CC BY-NC-ND license (http://creativecommons.org/licenses/by-nc-nd/4.0/)
This can have number of major profitable and ecological collision, which include reduce freshwater storeroom facility, pollution of freshwater invention wells, soil salinization, and reduce nutrient loaded freshwater release to marine ecology (Johnnes,1980; Taniguchi et al.,2002). The usual stability among the freshwater and saltwater in coastal aquifer has been troubled by over-exploitation of groundwater to collect the demand of freshwater; this activity reduces the level of freshwater and causes the sea water intrusion. The SWI, also, is caused by lesser of water table by drainage channel, Urbanization, population increases, lower rate of groundwater recharge and agricultural activities.In Figure 1 shows the detailed variation about the good, contaminated and sea water by the source of foremost cat ions and anions. The quality of groundwater can be determined with the presence of parameters. The good quality of $\mathrm{GW}$ holds the smaller percentage of $\mathrm{cl}+\mathrm{NO}_{3}$ and $\mathrm{Na}+\mathrm{K}$ combination. As, the sea water contains the higher percentage of $\mathrm{Cl}+\mathrm{NO}_{3}$ and $\mathrm{Na}+\mathrm{K}$ combination. The variation has been further explained with the ratio of $\mathrm{Cl} /\left(\mathrm{CO}_{3}+\mathrm{HCO}_{3}\right)$ at 0.5 for Good $\mathrm{GW}, 2.8$ for contaminated GW and 200 for sea water. There are various methods available for the assessment of SWI namely Geophysical GALDIT, groundwater ions. In this study, the sea water intrusion is addressed by means of geochemical. Some particular ions such as $\mathrm{Cl}^{-}, \mathrm{Na}^{2+}, \mathrm{Mg}^{2+}, \mathrm{SO}_{4}{ }^{2-}$ and $\mathrm{Br}$ in groundwater are improve by seawater intrusion and is can be utilize as a marker of its influences (Youngyun Park et al., 2011). For the assessment, the groundwater samples are collected and tested by laboratory method for both pre and post-monsoon period and using the results the spatial maps for all determined parameters are prepared for the analysis purpose. Further, the

Gibs Reconstructed diamond field of piper diagram. Permeability index and Salinity and sodium hazard of irrigation water in US salinity diagrams are obtained using the watclast software.

\section{STUDY AREA}

Parangipettai was known as PORTNOVO (a Dutch Team). The meaning of Parangipettai was town of white inhabitants, the Europeans. The Parangipettai block is located at the north latitude of $11^{\circ} 56^{\prime}$ and $11^{\circ} 41^{\prime}$ and east longitude of $79^{\circ} 65^{\prime}$ and $79^{\circ} 83^{\prime}$.

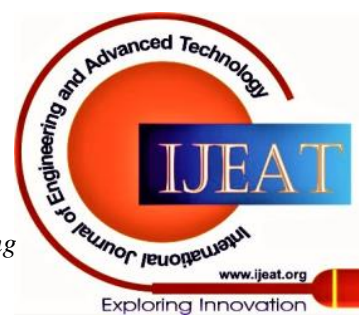


Hydro-geochemical Assessment of Seawater Intrusion in Freshwater Shallow Aquifer in Southeastern Coastal of Cuddalore District, Tamilnadu, India

The total geographical area of the block is 22898 ha with coastal line of $24 \mathrm{~km}$. The boundaries of the block are Bay of Bengal on the east, Keerapalayam and Bhuvanagiri, Kurinjipadi, Kumaratchi on the west, north and south respectively in Figure 2.

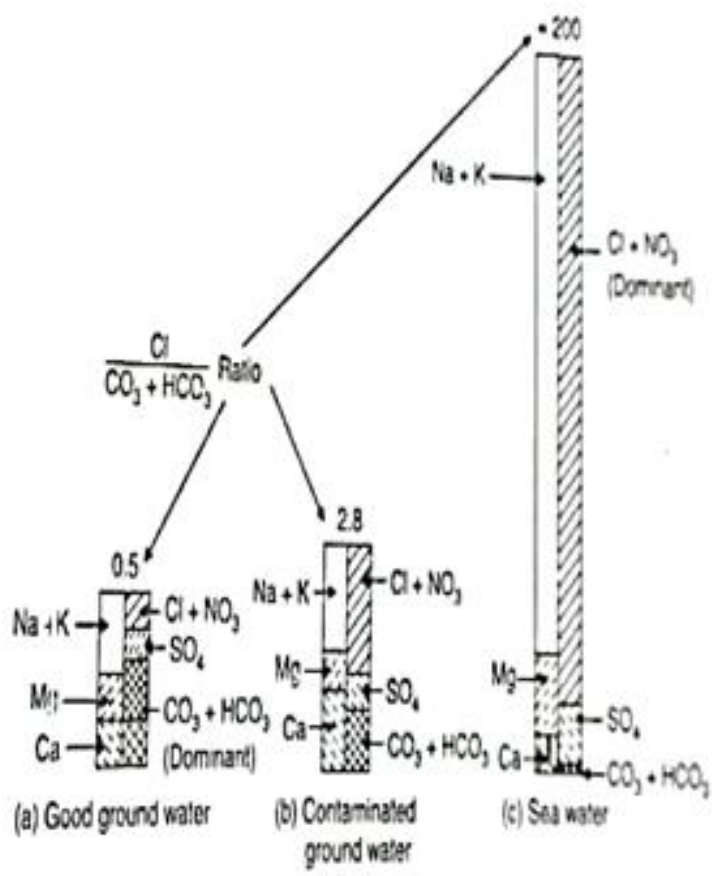

Fig. 1 Groundwater Contamination

There are two major, medium or even minor industrial units in the block and the block is industrially backward. The ancient place called Thiruvetkulam (now being called Tiruvakkulam) and the present Annamalai nagar are located near the block. The chola built town Chidambaram (Nataraja Temple) is $21 \mathrm{Km}$ away from the block headquarters. The world-famous Mangrove forests of Pichavaram and the Annamalai University Marine Biology Research station are located within the block. The Mangrove forests of Pichavaram attract Tourists from maps for all the determined parameters are prepared for the analysis purpose. Further, the Gibbs, far and near.

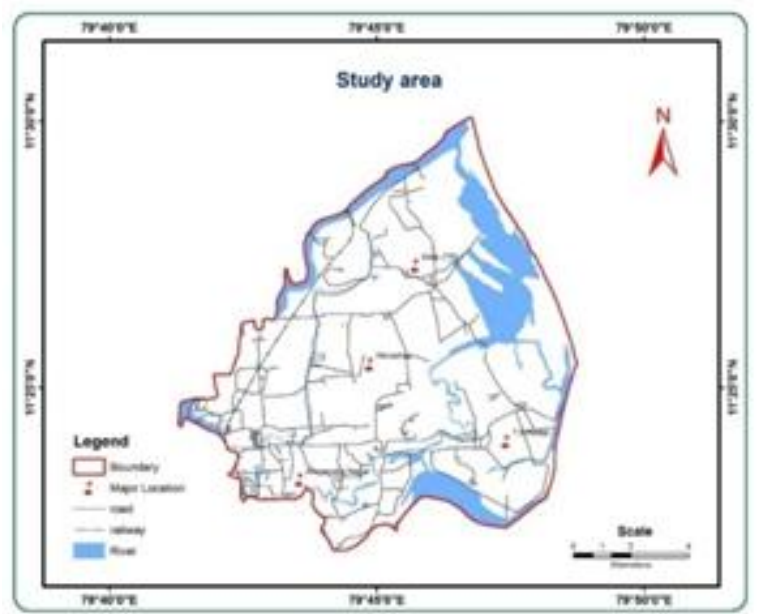

Fig. 2 Study area map of Parangipettai region

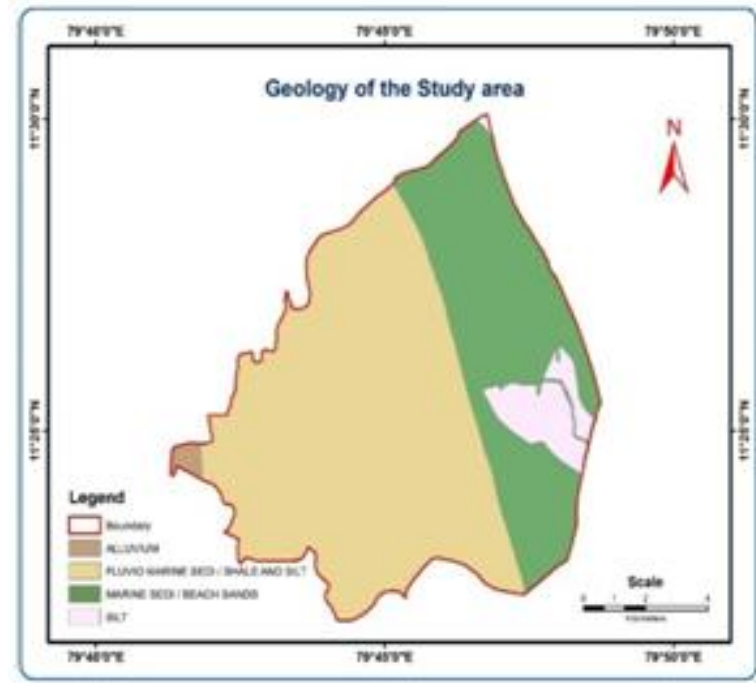

Fig. 3 Geology map of study area

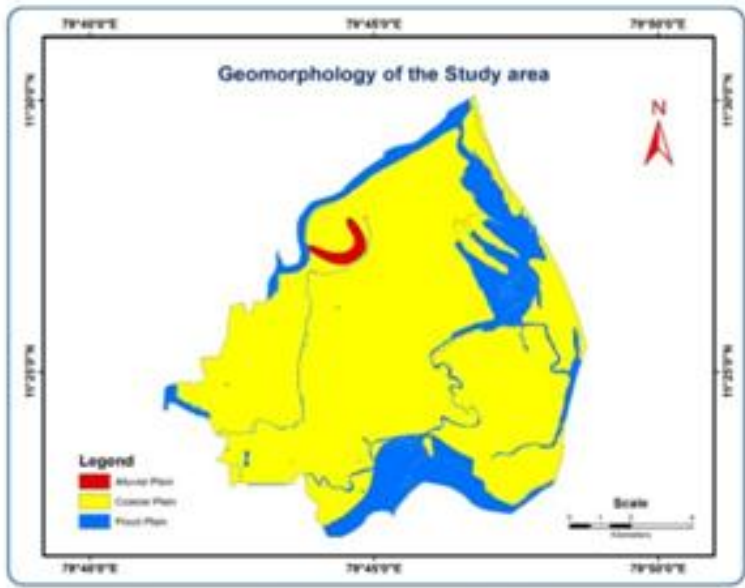

Fig. 4 Geomorphology map of study area

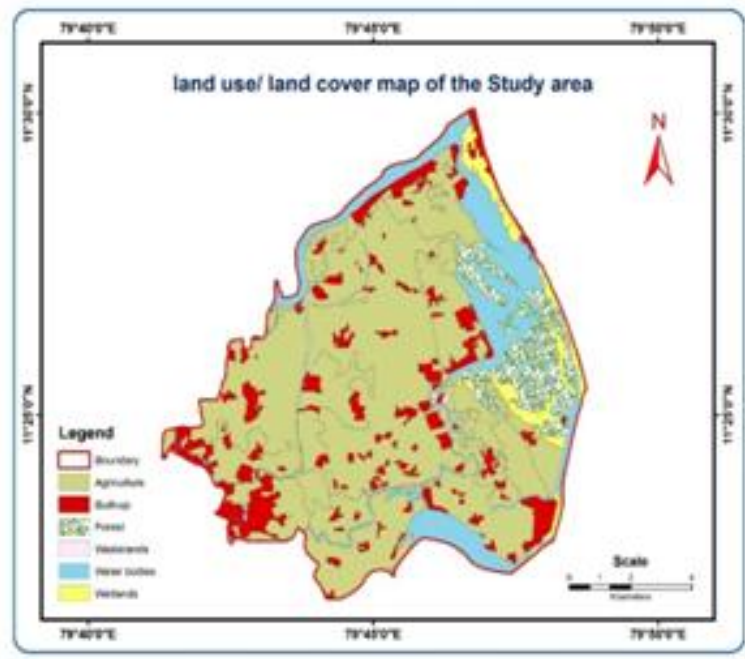

Fig. 5 Land use/Land cover map of the study area

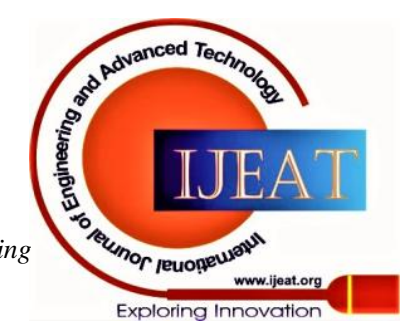




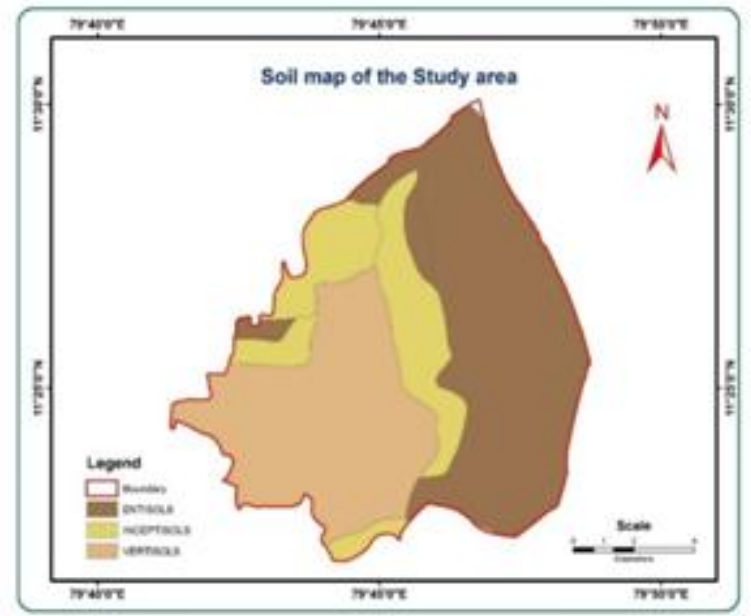

Fig. 6 Soil map of the study area

\section{A. Geology and Geomorphology}

The spatial map of geology provides the platform for better understanding of geology and the geomorphology pattern of Parangipettai block in Figure 3 and Figure 4. The $70 \%$ of the study area is covered by fluvio marine sediment/ shale and silt in the locations like Thillaividangan, Pinnathur, Melthirukazhipalai, Nakkaravanthangudi, Chidambaramthanprttai and Najaimahathu valkai. The location like Killai, Pichavaram, Kelthirukazhipalai have marine sediment and beach sand which is about $20 \%$ of study area. There is good deal between SWI and marine sediment and $5 \%$ of silt present in this block. There is some minor percentage of alluvium in the Pallipadai location.

The block is influenced by three plains namely coastal, flood and alluvial plains. The coastal plains mean the lowlying land adjacent to a sea-coast. The coastal plains have the threat of SWI. Thus, the block containing coastal plains largely indicates the SWI problems in the study area. There are some low amount of alluvial plains and a considered percentage of flood plains in the location like Melthirukazhipalai, Keelthirukazhipalai and Killai.

The land use/ land cover pattern of the Parangipettai is given in the spatial map. The Figure 5 shows the major percentage of the block used as agricultural land. The villages like Killai, Kelthirukazhipalai, and Pichavaram have water bodies besides some of the wetlands and forest areas (mangrove forest). The region holds some built-up land surfaces.

The soil type of the Parangipettai was analyzed with spatial map in Figure 6. The region holds $40 \%$ of Entisols in the locations like Killai, Pichavram, and Keelthirukazhipalai. The coastal zone of the block has smaller areas with Inceptisols. Vertisols is formed in the regions like Sithalapadi, Kumaramangalam, Chidamabaramthanpettai, Nakkaravanthangudi.

\section{METHODOLOGY}

For the review of groundwater feature, groundwater trials were gathered in the summer (August) and winter (February) seasons in the year 2019 and 2020 from the represented hand pumps spread all over the revise region which are used for domestic, drinking and irrigation purposes. Figure 7 shows as trial were examine for the presence of major and minor ions $(\mathrm{pH}$, Electrical conductivity, Total Dissolved solids, Calcium, Magnesium, Potassium, Sodium, Chloride, Sulphate, Bi-carbonate and Total Hardness concentrations) by following the usual technique propose by APHA (2005).

Prior to the collection of samples, the bottles were completely washed with diluted $\mathrm{HNO}_{3}$ acid and then with distilled water, before filling the bottle with the sample. It will be rinsed three times for the conformation of cleanliness in bottling and other precautions too.

The $\mathrm{pH}$ and EC were determined by multi-parameter kid. The Total dissolved solids was calculated by multiplying EC with 0.650. Carbonate and Bicarbonate were determined by titration with the Hcl. Chloride was analyzed by titration with the AgNo3. Sulphate was resolute by UV-spectrometer. Calcium and Magnesium were estimated by titration with the EDTA. Sodium and Potassium were resolute by using Flame photometer.

The obtained results were compared with standards provided by World Health Organization. The spatial maps were prepared for all the determined parameter for the purpose of better understanding the quality of Groundwater. The error correction was applied to the results obtained by laboratory method for achieving better accuracy. The error was found less than $+5 \%$ for all the samples. The permeability index, Gibbs, Salinity and sodium risk of irrigation water in US salinity diagram and reconstructed diamond field of piper diagrams were carried out using the Watclast software.

\section{RESULTS AND DISCUSSIONS}

The quality of groundwater was justified by means of its parameter. The results were evaluate with the principles provide by various organization (WHO,

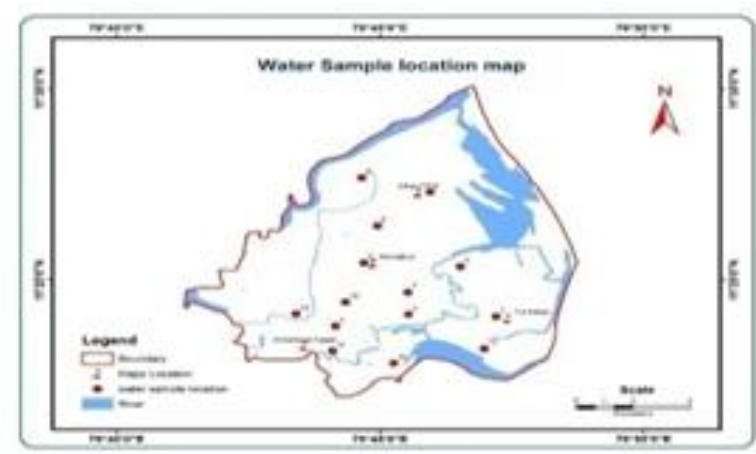

Fig. 7 Water sample location

BIS and ISI) and tabulated in Table 1 . For better and detailed assessment, the classification of GW was carried out on the basis of sodium percentage, SAR, RSC, EC, TDS, $\mathrm{PI}$, hardness and chloride classification as provided in Table 2.

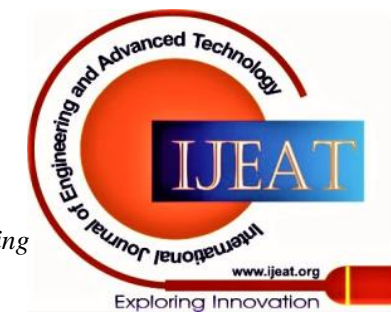




\section{A. Investigation of Groundwater Quality}

The $\mathrm{pH}$ varies from 6.47 to 8.46 with the mean of 7.574 and 6.91 to 9.46 with 7.714 in pre and post-monsoon in the study area. The groundwater from the study area was originated to be alkaline in nature. The $\mathrm{pH}$ was found within the allowable limit as recommended by WHO and BIS.

EC range from 712 to $6712 \mu \mathrm{s} / \mathrm{cm}$ with mean of 1926.429 $\mu \mathrm{s} / \mathrm{cm}$ in pre-monsoon period and it ranged from 503 to $5360 \mu \mathrm{s} / \mathrm{cm}$ with mean of $1717.077 \mu \mathrm{s} / \mathrm{cm}$. From the EC (Wilcox, 1955) classification excellent $(<250 \mu \mathrm{s} / \mathrm{cm})$, Good (250-750 $\mu \mathrm{s} / \mathrm{cm})$, permissible (750-2250 $\mu \mathrm{s} / \mathrm{cm})$, Doubtful (2250-5000 $\mu \mathrm{s} / \mathrm{cm})$, unsuitable (>5000 $\mu \mathrm{s} / \mathrm{cm})$. Totally, 7 and $21 \%$ of sample falls in excellent group in the pre and post-monsoon; 71 and $50 \%$ of sample falls in the permissible variety for both pre and post-monsoon; 14 and $21 \%$ of samples falls in doubtful; and about $1 \%$ of sample for both the monsoon fall under unsuitable category. The higher level of EC, in groundwater, is the indicator of salinity.

Total dissolved solids vary from 326.9 to $\quad 3484 \mathrm{mg} / \mathrm{l}$ with average value of $1154.292 \mathrm{mg} / \mathrm{l}$ and 462 to $4363 \mathrm{mg} / \mathrm{l}$ with average value of $\quad 1150.643 \mathrm{mg} / \mathrm{l}$ in the pre and post-monsoon period. Greater percentage of TDS causes undesirable taste due to salinity intrusion and other anthropogenic activities. From the TDS (freeze and Cherry 1979) about 50 and $79 \%$ of samples comes under the moderately saline category. The 21 and $7 \%$ of sample falls in very saline class. The permissible limit provided by WHO is $1500 \mathrm{mg} / \mathrm{l}$. Most of the samples have higher TDS value in the locations like Kumaramangalam, Thillaividangan and Uthamasozhamangalam.

Total hardness ranges from 130 to $964 \mathrm{mg} / \mathrm{l}$ with the mean value of $460.7143 \mathrm{mg} / \mathrm{l}$ in the pre-monsoon. It lies between 3.7 and $268 \mathrm{mg} / \mathrm{l}$ with the mean value of $34.9 \mathrm{mg} / \mathrm{l}$. totally, $43 \%$ of samples are found beyond the allowable limit in premonsoon and all the samples are found within the allowable limit in the post-monsoon period (WHO, $500 \mathrm{mg} / \mathrm{l}$ ). From the sawyer and McCarty classification,

the TH is soft at $<75$, slightly hard at $75-150 \mathrm{mg} / \mathrm{l}$, moderately hard at $150-300 \mathrm{mg} / \mathrm{l}$ and very hard at $>300 \mathrm{mg} / \mathrm{l}$. About $93 \%$ of the sample falls in very hard in the pre-monsoon and $7 \%$ of the sample falls under very hard group in the postmonsoon.

Calcium concentration varies from 28.9 to $\quad 832.7 \mathrm{mg} / \mathrm{l}$ with mean value of $401.04 \mathrm{mg} / \mathrm{l}$ in the pre-monsoon period and 3.8 to $292 \mathrm{mg} / \mathrm{l}$ with mean value of $46.3 \mathrm{mg} / \mathrm{l}$ in the postmonsoon period. The concentration of magnesium varies from 38.4 to $120 \mathrm{mg} / \mathrm{l}$ with average value of $53.464 \mathrm{mg} / \mathrm{l}$ and 1.28 to $57 \mathrm{mg} / \mathrm{l}$ with mean value of $9.525 \mathrm{mg} / \mathrm{l}$ in the pre and post-monsoon duration. About $79 \%$ of samples and $7 \%$ sample of calcium are found beyond the allowable limit suggested by WHO as $200 \mathrm{mg} / \mathrm{l}$. The groundwater samples are found within the allowable limit provided by WHO, ISI and BIS.

Potassium concentration varies from 2 to $134 \mathrm{mg} / \mathrm{l}$ with the mean value of $51.63 \mathrm{mg} / \mathrm{l}$ and from 7.5 to $722 \mathrm{mg} / \mathrm{l}$ with the signify value of $29.321 \mathrm{mg} / \mathrm{l}$ during the pre and post-monsoon period. The presence of greater percentage is an indicator of SWI and $71 \%$ and $79 \%$ of samples are beyond the permissible limit in the pre and post-monsoon period (WHO, $12 \mathrm{mg} / \mathrm{l}$ ).

The concentration of sodium lies between 37.5 to 610 $\mathrm{mg} / \mathrm{l}$ with the mean value of $222.61 \mathrm{mg} / \mathrm{l}$ in the pre-monsoon and between 10 to $177.6 \mathrm{mg} / \mathrm{l}$ with mean value of 105.02 $\mathrm{mg} / \mathrm{l}$ in the post-monsoon period. The $50 \%$ of the trial are found beyond the limit (WHO $200 \mathrm{mg} / \mathrm{l}$ ) in the pre-monsoon period. As, all the samples are found within the limit in the post-monsoon.

Bicarbonate ranges from 3.9 to $14.2 \mathrm{mg} / \mathrm{l}$ with the mean value of $9 \mathrm{mg} / \mathrm{l}$ and from 0.5 to 14.2 with imply value of $4.21 \mathrm{mg} / \mathrm{l}$ during the pre and post-monsoon. It was found within the permissible limit.

Chloride concentration differ from 106 to $1392 \mathrm{mg} / \mathrm{l}$

with mean value of $398.57 \mathrm{mg} / \mathrm{l}$ in the pre-monsoon and in the post-monsoon; it varies from 1 to $132 \mathrm{mg} / \mathrm{l}$ with mean value of $24.60 \mathrm{mg} / \mathrm{l}$. Totally, $21 \%$ of trial beat the permissible limit (WHO 600mg/l) in the pre-monsoon and all the samples are found within the permissible limit in the post-monsoon duration. From the chloride classification (stuyfzand,1989) 21\% of trial drop under fresh, $29 \%$ of samples fall under fresh brackish, $43 \%$ of trail drop under in brackish and $7 \%$ of trail drop under brackish salt water in the pre-monsoon period. In the post-monsoon period, $21 \%$ of the samples represent extremely fresh water, $57 \%$ of samples represent very freshwater water and $21 \%$ of samples represent fresh water category.

Sulphate concentration varies from 20 to $80 \mathrm{mg} / \mathrm{l}$ with average value of $45.29 \mathrm{mg} / \mathrm{l}$ in the pre-monsoon and 0.01 to $48 \mathrm{~m} / \mathrm{l}$ with the mean value of $3.83 \mathrm{mg} / \mathrm{l}$. All the samples are found within the permissible limit (WHO, 250mg/l).

The cationic concentration represents the type of $\mathrm{Na}>\mathrm{Ca}$ $>\mathrm{K}>\mathrm{Mg}$ of $50 \%$ followed by

$\mathrm{Na}>\mathrm{K}>\mathrm{Mg}>\mathrm{Ca}$ and $\mathrm{Na}>\mathrm{K}>\mathrm{Ca}>\mathrm{Mg}$ of about $14 \%$ and the minor concentrations of about $7 \% \mathrm{~K}>\mathrm{Na}>\mathrm{Ca}>$ $\mathrm{Mg}$ and $\mathrm{Ca}>\mathrm{K}>\mathrm{Mg}>\mathrm{Na}$ type.

The anionic concentration represents $79 \%$ of $\quad \mathrm{Cl}>$ $\mathrm{HCO}_{3}>\mathrm{SO}_{4}$ and $7 \%$ of $\mathrm{Cl}>\mathrm{SO} 4>\mathrm{HCO} 3$ type and minor concentration of about $\mathrm{HCO}_{3}>\mathrm{Cl}>\mathrm{SO}_{4}$ type. The anionic concentration about $86 \%$ is the chloride dominant. From the ionic concentration, it was found that the chloride and sodium is dominant ion in the groundwater of study area. The sodium and chloride are key indicators of seawater.

Table: 1 Groundwater sample result is compared with the standards provided by WHO, BIS and ISI

\begin{tabular}{|c|c|c|c|c|c|c|c|c|c|}
\hline \multirow[b]{2}{*}{ Parameter } & \multicolumn{3}{|c|}{ PRE-MONSOON } & \multicolumn{3}{|c|}{ POST-MONSOON } & \multirow{2}{*}{$\begin{array}{c}\text { STANDARDS } \\
\text { WHO } \\
(2004)\end{array}$} & \multirow[b]{2}{*}{$\begin{array}{c}\text { ISI } \\
(1983)\end{array}$} & \multirow[b]{2}{*}{$\begin{array}{c}\text { BIS } \\
(1991)\end{array}$} \\
\hline & Min & Max & Average & Min & Max & Average & & & \\
\hline pH & 6.47 & 8.46 & 7.573571 & 6.91 & 9.46 & 7.713571 & $6.5-8.5$ & $6.5-9.2$ & $6.5-8.5$ \\
\hline TH & 130 & 964 & 460.7143 & 3.7 & 268 & 34.9 & 500 & 600 & 600 \\
\hline
\end{tabular}




\begin{tabular}{|c|c|c|c|c|c|c|c|c|c|}
\hline EC & 712 & 6712 & 1926.429 & 503 & 5360 & 1717.077 & 1500 & - & - \\
\hline TDS & 326.9 & 3484 & 1154.292 & 462 & 4363 & 1150.643 & 1500 & 1500 & 2000 \\
\hline $\mathrm{Ca}$ & 28.9 & 832.7 & 401.0429 & 3.8 & 292 & 46.3 & 200 & 200 & 200 \\
\hline Mg & 38.4 & 120 & 53.46429 & 1.28 & 57 & 9.525 & 150 & 100 & 100 \\
\hline $\mathrm{Na}$ & 37.5 & 610 & 222.6071 & 10 & 177.6 & 105.0214 & 200 & - & 150 \\
\hline $\mathbf{K}$ & 2 & 134 & 51.62857 & 7.5 & 722 & 29.32143 & 12 & - & - \\
\hline SO4 & 20 & 80 & 45.28571 & 0.01 & 48 & 3.830714 & 250 & 400 & 400 \\
\hline $\mathrm{Cl}$ & 106 & 1392 & 398.5714 & 1 & 132 & 24.60714 & 600 & 1000 & 1000 \\
\hline HCO3 & 3.9 & 14.2 & 8.992857 & 0.5 & 14.2 & 4.214286 & 500 & - & 400 \\
\hline
\end{tabular}

Table 2: Groundwater classification based on sodium percentage, SAR, RSC, EC, TDS, PI, hardness and chloride

\section{Pre-Monsoon}

Na\% - (Wilcox, 1955)

\begin{tabular}{|lll}
\hline Groundwater class Range & \multicolumn{1}{c}{ No of samples } & \\
\hline Excellent & $0-20$ & 2 \\
\hline Good & $20-40$ & 10 \\
\hline Permissible & $40-60$ & 2 \\
\hline Doubtful & $60-80$ & 0 \\
\hline Unsuitable & $>80$ & 0
\end{tabular}

\section{S.A.R. - (Richards, 1954}

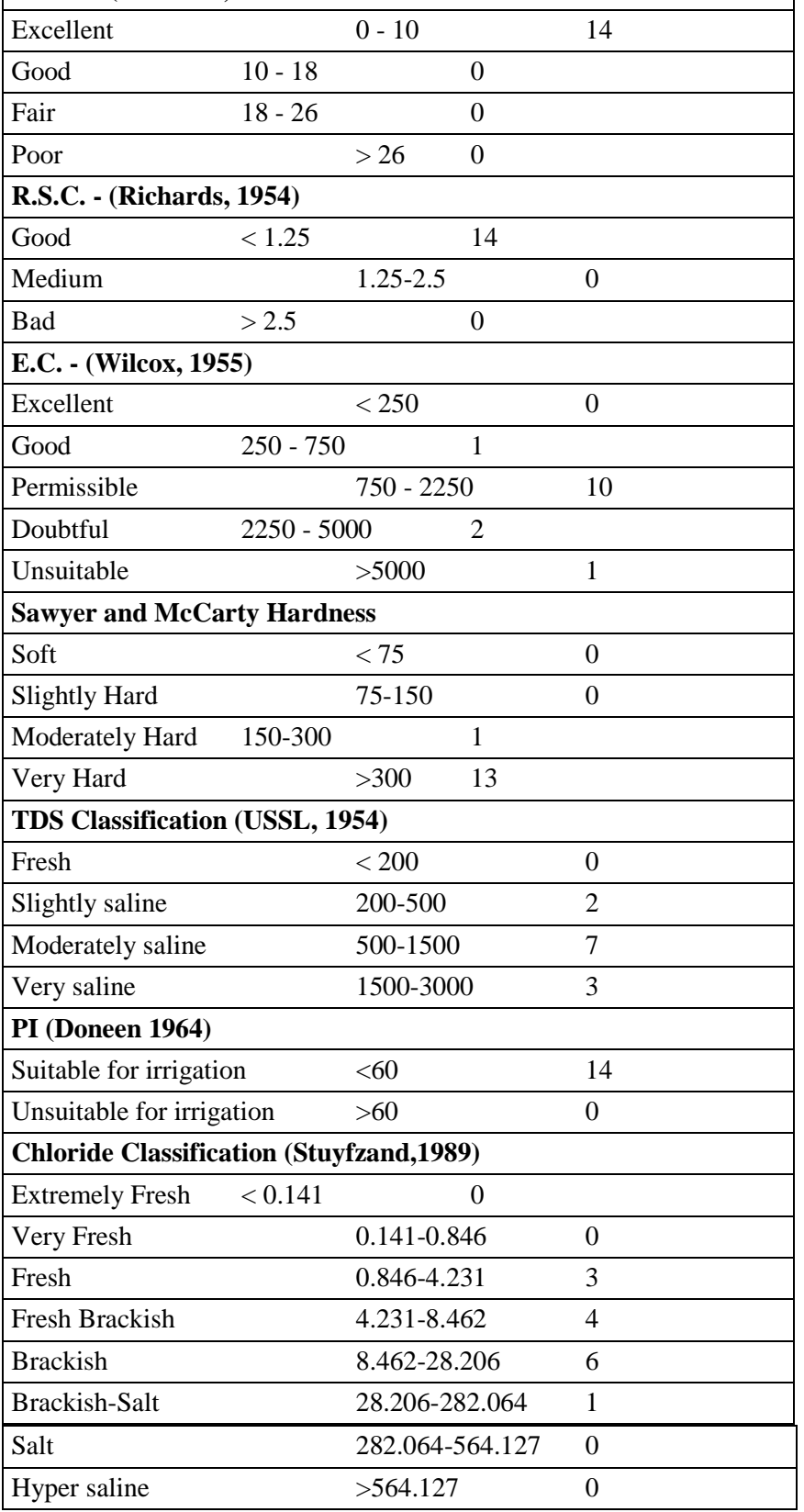

Post-Monsoon

Na\% - (Wilcox, 1955)

Groundwater class Range No of samples

\begin{tabular}{lll}
\hline Excellent & $0-20$ & 1 \\
\hline Good & $20-40$ & 0 \\
\hline Permissible & $40-60$ & 1 \\
\hline Doubtful & $60-80$ & 8 \\
\hline Unsuitable & $>80$ & 4
\end{tabular}

S.A.R. - (Richards, 1954)

\begin{tabular}{|c|c|c|}
\hline Excellent & & \\
\hline Good & $10-18$ & 1 \\
\hline Fair & $18-26$ & 0 \\
\hline Poor & & \\
\hline
\end{tabular}

R.S.C. - (Richards, 1954)

\begin{tabular}{llll}
\hline Good & $<1.25$ & 14 \\
\hline Medium & & $1.25-2.5$ & 0 \\
\hline Bad & $>2.5$ & 0 &
\end{tabular}

E.C. - (Wilcox, 1955)

Excellent $<250 \quad 0$

\begin{tabular}{|lcc|}
\hline Good & $250-750$ & 3 \\
\hline Permissible & $750-2250$ & 7 \\
\hline
\end{tabular}

\begin{tabular}{|lcc|}
\hline Doubtful & $2250-5000$ & 3 \\
\hline Unsuitable & $>5000$ & 1 \\
\hline
\end{tabular}

\section{Sawyer and McCarty Hardness}

\begin{tabular}{|c|c|c|c|}
\hline Soft & & $<75$ & 6 \\
\hline Slightly Hard & & $75-150$ & 6 \\
\hline Moderately Hard & $150-300$ & & \\
\hline Very Hard & & $>300$ & 1 \\
\hline
\end{tabular}

TDS Classification (USSL, 1954)

\begin{tabular}{|lll|}
\hline Fresh & $<200$ & 0 \\
\hline Slightly saline & $200-500$ & 1 \\
\hline Moderately saline & $500-1500$ & 11 \\
\hline Very saline & $1500-3000$ & 1 \\
\hline PI (Doneen 1964) & & \\
\hline Suitable for irrigation & $<60$ & 2 \\
\hline Unsuitable for irrigation & $>60$ & 12 \\
\hline
\end{tabular}

\section{Chloride Classification (Stuyfzand,1989c)}

\begin{tabular}{lll}
\hline Extremely Fresh $\quad<0.141 \quad 3$
\end{tabular}

\begin{tabular}{|lll|}
\hline Very Fresh & $0.141-0.846$ & 8 \\
\hline Fresh & $0.846-4.231$ & 3 \\
\hline Fresh Brackish & $4.231-8.462$ & 0 \\
\hline Brackish & $8.462-28.206$ & 0 \\
\hline Brackish-Salt & $28.206-282.064$ & 0 \\
\hline Salt & $282.064-564.127$ & 0 \\
\hline Hyper saline & $>564.127$ & 0 \\
\hline
\end{tabular}

\section{B. Hydrogeochemical Facies}

Published By:

Blue Eyes Intelligence Engineering

and Sciences Publication

(C) Copyright: All rights reserved.

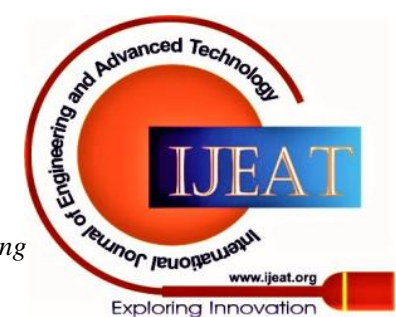




\section{Sodium Absorption Ratio}

In the assessment of SWI, the sodium is the vital parameter; where the higher percentage of sodium, in the groundwater indicates the presence of salinity. It also influence the soil property leading to drop of soil permeability.

$\mathrm{SAR}=\mathrm{Na} / \sqrt{(\boldsymbol{C a}+\boldsymbol{M g}) / 2}$

Table 2 shows the Groundwater classification (with reference to SAR by Richards 1954) with all the samples being categorized as excellent in the pre-monsoon period. Where, $93 \%$ of sample fall under excellent class and $7 \%$ of sample fall under good groundwater class in the postmonsoon period.

\section{Sodium percentage}

Sodium proportion in the groundwater is important parameter for the analysis of SWI. It helps to classify the irrigation water, because it reduces or replaces the calcium and magnesium in the soil, which causes reduction in the soil permeability affecting the plant growth.

Sodium percentage $=(\mathrm{Na}+\mathrm{K})$

$$
(\mathrm{Ca}+\mathrm{Mg}+\mathrm{Na}+\mathrm{K})
$$

Table 2 shows the Groundwater classification on the basis of sodium percentage by Wilcox 1955, with $14 \%$ percent of the samples falling in excellent class, $71 \%$ of the samples falling in good groundwater class, and $14 \%$ of the samples falling in the permissible groundwater class in the premonsoon period. About $57 \%$ of the trial fall under the doubtful group and $29 \%$ of the trial drop less than the unsuitable groundwater class in the post-monsoon period.

\section{Permeability Index (PI)}

The permeability index is used to categorize the irrigation water. With reference to the groundwater classification by Doneen 1964, Table 2 shows the samples as suitable for the irrigation category in the pre-monsoon period. Totally, $14 \%$ of sample fall under the suitable category and $86 \%$ of sample fall under the unsuitable category for irrigation in the post-monsoon period.
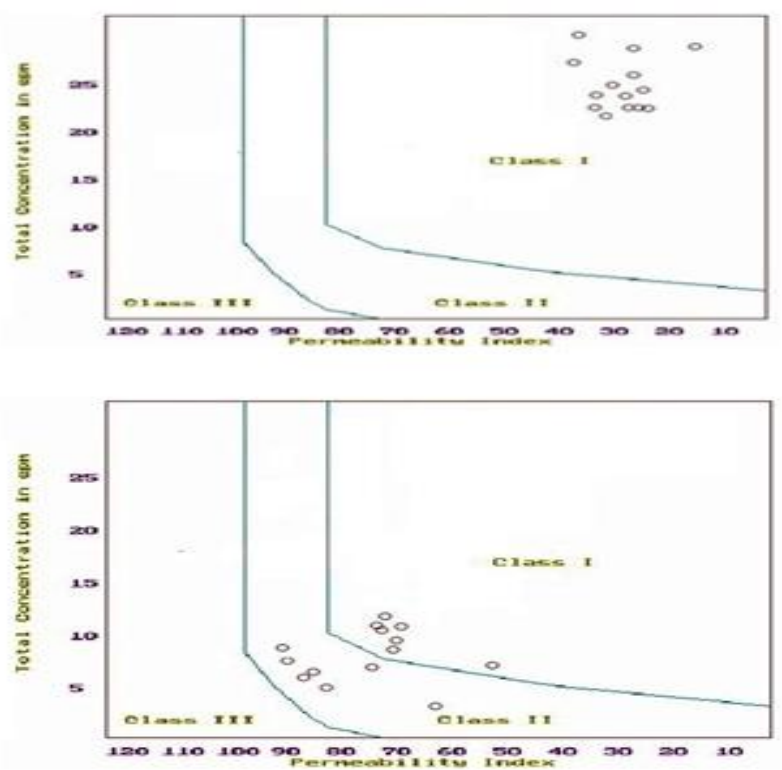

Fig. 8 Classification for irrigation water for soil of medium permeability (Domean, 1964)
The PI is used to classify the irrigation water (Doneen, 1964) from the Figure 8, all the collected GW samples fall under the class 1 type identified in the pre-monsoon. The graph is drawn for total concentration versus permeability index. From the figure, about $50 \%$ of collected GW samples fall under the class 1 type and $50 \%$ of trial drop in the class II type in post-monsoon.

\section{Wilcox Diagram}

The United States Salinity laboratory provided the diagram for classification of irrigation. The USSL diagram gives 16 classes for detail analysis. The diagram shows salinity hazard versus sodium hazard. The Figure 9 shows $14 \%$ of the trial drop in C4S1to indicates very high salinity hazard and low sodium hazard, $7 \%$ falling in C2S1to represent medium salinity hazard and low sodium hazard and $79 \%$ of GW samples falling in C3S1 to represent high salinity hazard and low sodium hazard in the pre-monsoon period. Totally, $7 \%$ of samples lies in C4S1, 7 \% lies in C4S2, 21 $\%$ of GW samples lies in C3S2, and $44 \%$ of samples falling in C3S1represents the high salinity hazard and low sodium hazard and $21 \%$ of GW trial drop in C2S1 to show the average salinity risk and low sodium risk in the postmonsoon period. From the result, it was confirmed that the more number of collected Groundwater sample declining in C3S1 group indicate the towering salinity hazard and little sodium risk in both the pre and post-monsoon period.

Sodium Hazard Salinity Hazard

$\begin{array}{ll}\text { S1: Low } & \text { C1: Low } \\ \text { S2: Medium } & \text { C2: Medium } \\ \text { S3: High } & \text { C3: High } \\ \text { S4: Very High } & \text { C4: Very High }\end{array}$

\section{Gibbs Diagram}

The various factors which control the groundwater chemistry can be analyzed with Gibbs diagram. The saline water shows the evaporation dominance and the fresh water shows the rock dominance. The Gibbs diagram was drawn between $\mathrm{Na} /(\mathrm{Na}+\mathrm{Ca})$ and $\mathrm{Cl} /\left(\mathrm{Cl}+\mathrm{HCO}_{3}\right)$ versus $\mathrm{TDSmg} / \mathrm{l}$ shown in Figure 10. In the pre-monsoon, The $\mathrm{Na} /(\mathrm{Na}+\mathrm{Ca})$ versus TDS mg/l

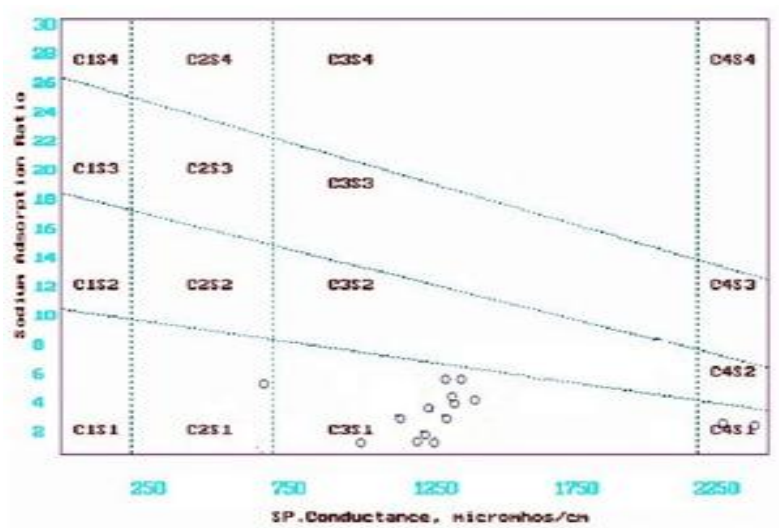

Fig. 9 US salinity laboratory classification for irrigation water

Published By: Blue Eyes Intelligence Engineering

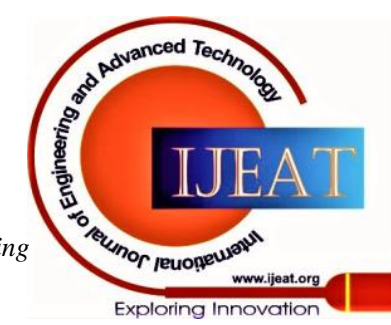



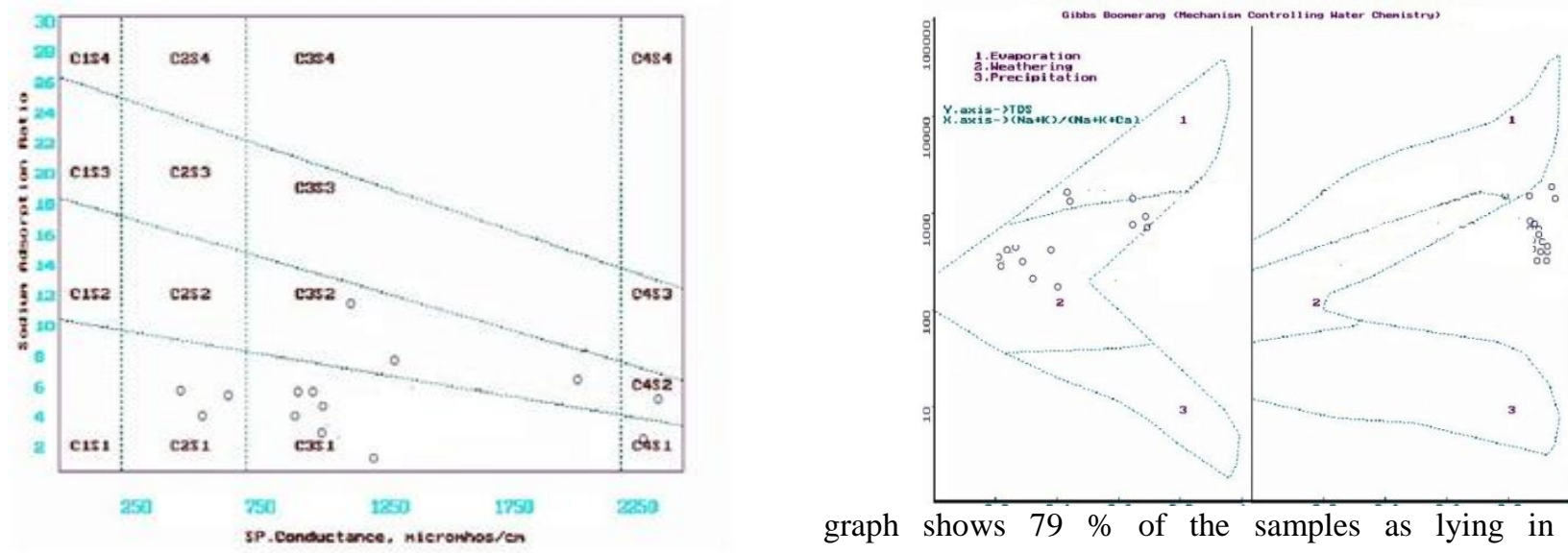

graph shows $79 \%$ of the samples as lying in rock dominance to indicate fresh water. The $\mathrm{Cl} /\left(\mathrm{Cl}+\mathrm{HCO}_{3}\right)$ versus TDS $\mathrm{mg} / \mathrm{l}$ showing all the samples falling under rock dominance represents freshwater. In the post-monsoon, both the graphs $\mathrm{Na} /(\mathrm{Na}+\mathrm{Ca})$ and $\mathrm{Cl} /\left(\mathrm{Cl}+\mathrm{HCO}_{3}\right)$ versus TDS $\mathrm{mg} /$ showing the $14 \%$ of samples come under evaporation dominance which indicate saline water and $86 \%$ of GW samples lying in rock dominance indicate freshwater

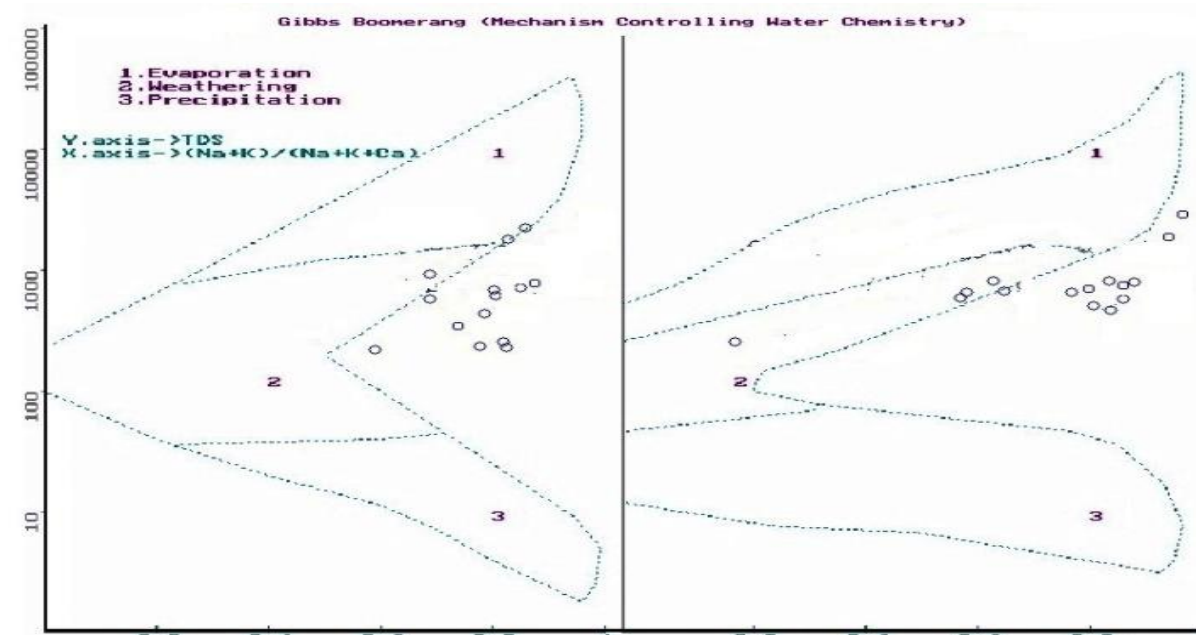

Fig.10 Gibbs diagram illustrating mechanism controlling the chemistry of groundwater samples

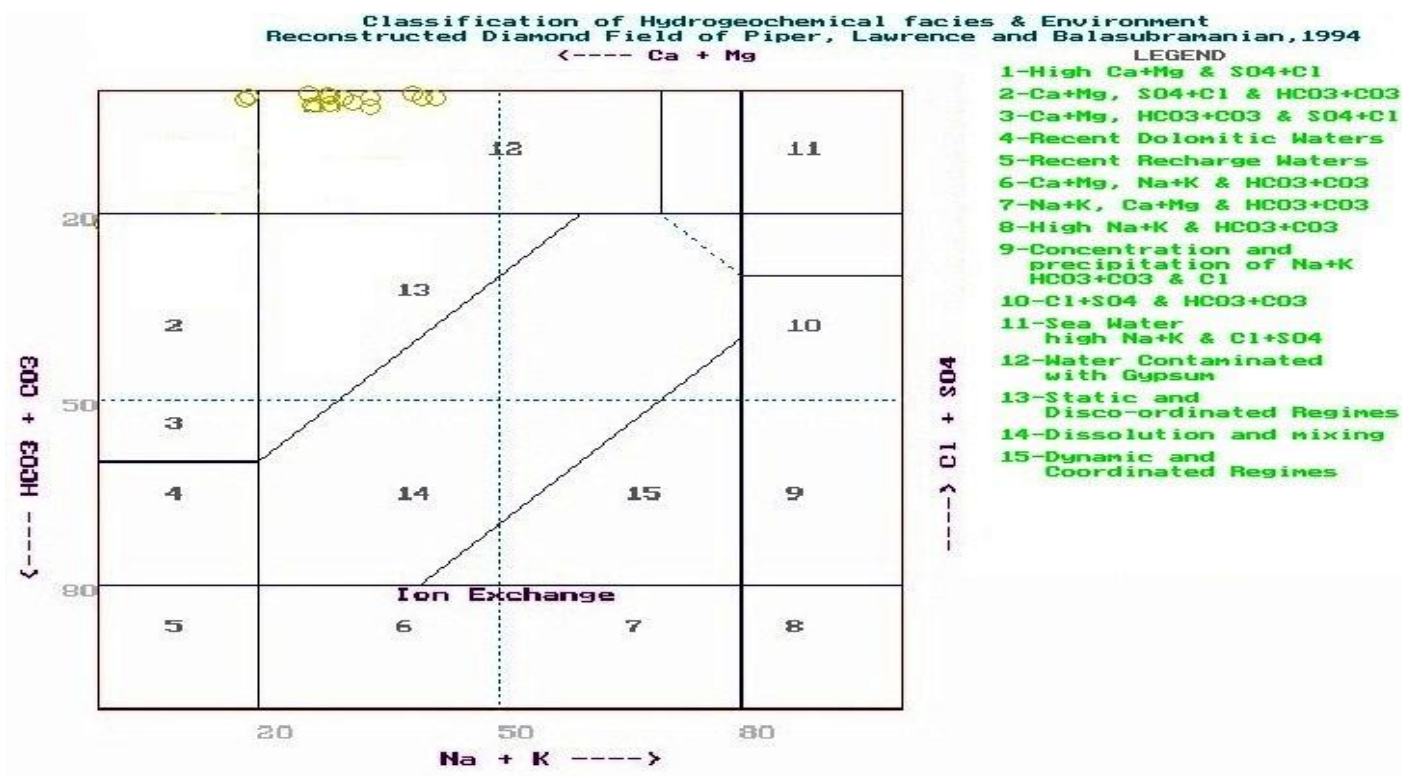




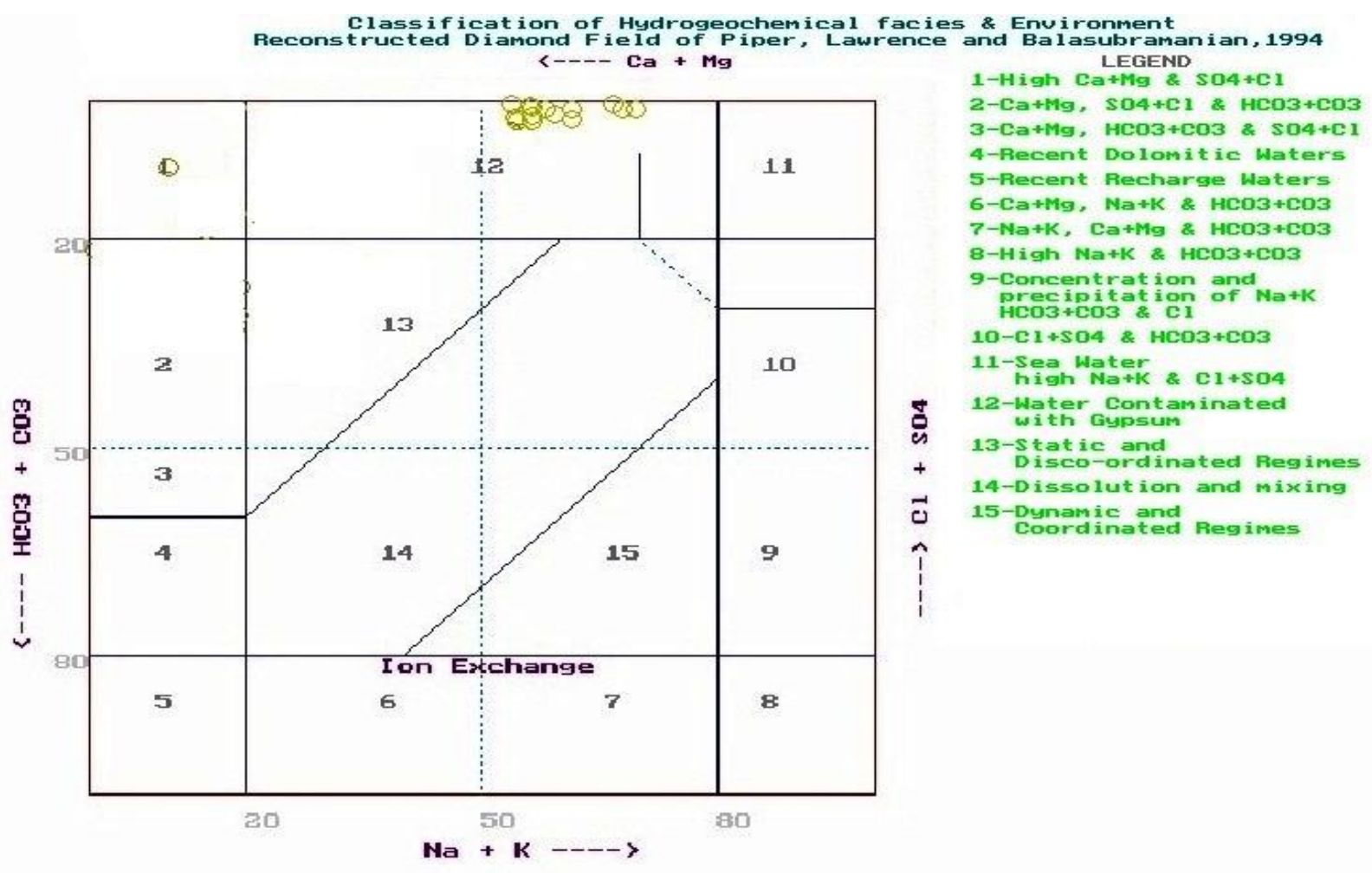

Fig. 11 Reconstructed Diamond field of Piper diagram

\section{Reconstructed Diamond field of Piper diagram}

From the reconstructed diamond field of piper diagram shown in Figure 11, 86\% of collected GW samples falling under the field number 12 to indicate the water contaminated with gypsum category and $14 \%$ of samples falling under the field number1 shows the High $\mathrm{Ca}+\mathrm{Mg}$ and $\mathrm{SO}_{4}+\mathrm{Cl}$ category in the pre-monsoon period. In the postmonsoon, all the samples lying in the field number 12 represent the water contaminated with gypsum

\section{CONCLUSION}

The Hydro geochemical assessment indicated that the groundwater samples are slightly alkaline in nature. The higher level of Electrical Conductivity, Total dissolved solids and chloride in some locations of the Parangipettai block confirmed the presence of the salinity in water which is unsuitable for drinking purpose. As the sodium and chloride are the important indicators of the salinity, The anionic concentration reveals the chloride ion dominance and the cationic concentration shows the sodium dominance. The USSL diagram indicated more number of groundwater sample falling under the C3S1category which represents high salinity and low sodium hazard.

Sodium Absorption ratio and sodium percent, permeability indexes refer to the majority of the trial as not fitting for irrigation. From the Hydrochemical assessment, it is determined that the water quality is not in safe zone. So, necessary precaution has to be taken to restore the quality of groundwater.

\section{REMEDIAL MEASURES:}

- Decrease the rates of abstraction,

- Relocation of abstraction works,

- Augment of natural recharge,

- $\quad$ Artificial recharge
- Abstraction of saline groundwater

\section{REFERENCES}

1. Adewuyi Gregory Olufemi, Oputu Ogheneochuko Utieyin, Opasina Mukaila Adebayo (2010), Assessment of Groundwater Quality and Saline Intrusions in Coastal Aquifers of Lagos Metropolis, Nigeria, J. Water Resource and Protection, 2, Pp. 849-853.

2. Cimino A, Cosentino C, Oieni A, Tranchina L (2008), A geophysical and geochemical approach for seawater intrusion assessment in the Acquedolci coastal aquifer (Northern Sicily), Environ Geol, 55, Pp. 1473-1482.

3. Costantino Masciopinto (2013), Management of aquifer recharge in Lebanon by removing seawater intrusion from coastal aquifers, Journal of environmental management, 130, Pp. 306-312.

4. David R, Pyne G (2015), Aquifer storage recovery: an ASR solution to saltwater intrusion at Hilton Head Island, South Carolina, USA Environ Earth Sci, 73, Pp. 7851-7859.

5. Haddouta S, Maslouhia A, Magraneb B, Igouzala M (2015), Study of salinity variation in the Sebou River Estuary (Morocco), Taylor and Francis, ISSN: 1944-3994

6. Klassen J, Allen DM (2017), Assessing the risk of saltwater intrusion in coastal aquifers, Journal of Hydrology, 551, Pp. 730-745

7. Meredith Goebel, Adam Pidlisecky, Rosemary knight (2017), Resistivity imaging reveals complex pattern of saltwater intrusion along Monetary coast, Journal of Hydrology, 551, Pp. 746-755.

8. Pauw PS, Groen J, Groen MMA, Van der made KJ, Stuyfzand PJ, Post VEA (2017), Groundwater Salinity Pattern along the Coast of the Western Netherland and the application of cone penetration tests, Journal of Hydrology, 551, Pp. 756-767.

9. Santha Sophiya M, Tajdarul H. Syed (2013), Assessment of vulnerability to seawater intrusion and potential remediation measures for coastal aquifers: a case study from eastern India, Environ Earth Sci, 70, Pp. 1197-1209.

10. Saxena S, Purvaja R, Mary Divya Suganya G, Ramesh R (2012), Coastal hazard mapping in the Cuddalore region, South India, Nat Hazards, 66, Pp. 1519-1536.

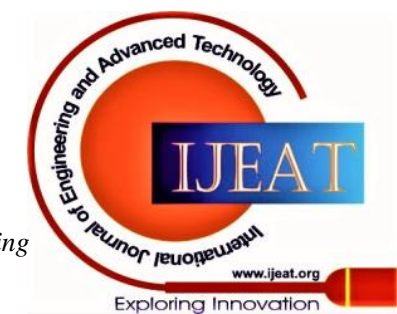

